University of Nebraska - Lincoln

DigitalCommons@University of Nebraska - Lincoln

US Department of Energy Publications

U.S. Department of Energy

2009

Newly recognized hosts for uranium in the Hanford Site vadose

zone

Joanne E. Stubbs

Johns Hopkins University, Department of Earth and Planetary Sciences, jstubbs1@jhu.edu

Linda A. Veblen

Johns Hopkins University, Department of Earth and Planetary Sciences

David C. Elbert

Johns Hopkins University, Department of Earth and Planetary Sciences

John M. Zachara

Pacific Northwest National Laboratory, john.zachara@pnl.gov

James A. Davis

U.S. Geological Survey

See next page for additional authors

Follow this and additional works at: https://digitalcommons.unl.edu/usdoepub

Part of the Bioresource and Agricultural Engineering Commons

Stubbs, Joanne E.; Veblen, Linda A.; Elbert, David C.; Zachara, John M.; Davis, James A.; and Veblen, David R., "Newly recognized hosts for uranium in the Hanford Site vadose zone" (2009). US Department of Energy Publications. 260.

https://digitalcommons.unl.edu/usdoepub/260

This Article is brought to you for free and open access by the U.S. Department of Energy at DigitalCommons@University of Nebraska - Lincoln. It has been accepted for inclusion in US Department of Energy Publications by an authorized administrator of DigitalCommons@University of Nebraska - Lincoln. 


\section{Authors}

Joanne E. Stubbs, Linda A. Veblen, David C. Elbert, John M. Zachara, James A. Davis, and David R. Veblen 


\title{
Newly recognized hosts for uranium in the Hanford Site vadose zone
}

\author{
Joanne E. Stubbs ${ }^{\mathrm{a}, *}$, Linda A. Veblen ${ }^{\mathrm{a}, \mathrm{b}}$, David C. Elbert ${ }^{\mathrm{a}}$, \\ John M. Zachara ${ }^{c}$, James A. Davis ${ }^{\mathrm{d}}$, David R. Veblen ${ }^{\mathrm{a}}$ \\ ${ }^{a}$ Johns Hopkins University, Department of Earth and Planetary Sciences, Baltimore, MD 21218, USA \\ ${ }^{\mathrm{b}}$ U.S. Nuclear Regulatory Commission, Rockville, MD 20852, USA \\ ${ }^{\mathrm{c}}$ Pacific Northwest National Laboratory, Richland, WA 99352, USA \\ ${ }^{\mathrm{d}}$ U.S. Geological Survey, Menlo Park, CA 94025, USA
}

Received 24 September 2008; accepted in revised form 7 December 2008; available online 24 December 2008

\begin{abstract}
Uranium contaminated sediments from the U.S. Department of Energy's Hanford Site have been investigated using electron microscopy. Six classes of solid hosts for uranium were identified. Preliminary sediment characterization was carried out using optical petrography, and electron microprobe analysis (EMPA) was used to locate materials that host uranium. All of the hosts are fine-grained and intergrown with other materials at spatial scales smaller than the analytical volume of the electron microprobe. A focused ion beam (FIB) was used to prepare electron-transparent specimens of each host for the transmission electron microscope (TEM). The hosts were identified as: (1) metatorbernite $\left[\mathrm{Cu}\left(\mathrm{UO}_{2}\right)_{2}\left(\mathrm{PO}_{4}\right)_{2} \cdot 8 \mathrm{H}_{2} \mathrm{O}\right] ;$; (2) coatings on sediment clasts comprised mainly of phyllosilicates; (3) an amorphous zirconium (oxyhydr)oxide found in clast coatings; (4) amorphous and poorly crystalline materials that line voids within basalt lithic fragments; (5) amorphous palagonite surrounding fragments of basaltic glass; and (6) Fe- and Mn-oxides. These findings demonstrate the effectiveness of combining EMPA, FIB, and TEM to identify solid-phase contaminant hosts. Furthermore, they highlight the complexity of U geochemistry in the Hanford vadose zone, and illustrate the importance of microscopic transport in controlling the fate of contaminant metals in the environment.

(C) 2008 Elsevier Ltd. All rights reserved.
\end{abstract}

\section{INTRODUCTION}

Terrestrial and subsurface uranium contamination is one of the most complex and intractable problems in environmental geochemistry today. The National Research Council estimates that there are more than 6 billion cubic meters of contaminated soil and groundwater in the U.S. Department of Energy (DOE) complex, much of it containing uranium (U). To date, the DOE has invested more than $\$ 100$ billion in the cleanup of sites involved in the processing of $U$ ores and the production of nuclear weapons, but there are still major gaps in the knowledge required for suc-

\footnotetext{
* Corresponding author. Fax: +1 4105167933.

E-mail address: jstubbs1@jhu.edu (J.E. Stubbs).
}

cessful cleanup and/or stewardship of these sites (Crowley, 2007). Remediation of $U$ environmental contamination involves an evaluation of various modeling scenarios that predict the fate and transport of $\mathrm{U}$, with conceptual models that incorporate a fundamental understanding of $U$ geochemistry (Davis, 2004).

A critical part of the conceptual model involves an identification of the solid-phase sources and sinks for U, including sorption and incorporation in minerals, glasses and other amorphous materials, and organic matter. Investigation of meaningful samples is usually difficult, however, because many U hosts are fine-grained, sparsely distributed, intimately intergrown with other phases, and prone to alteration during analysis. Further complication comes from the often complex and/or unknown history of contamination 
found at many sites. In this study, we evaluate the solidphase residence of contaminant $U$ in vadose zone sediments from the Columbia River corridor of DOE's Hanford Site, in south-central Washington. These samples exhibit a prolonged contamination history and present analytical challenges similar to those found at other sites throughout the U.S. DOE complex, as well as other U-containing sites worldwide.

The Hanford Site produced plutonium for World War II and the Cold War. Activities related to this production have left behind an extensive legacy of contaminated soils and groundwater (see, for example, Hartman et al., 2007; Zachara et al., 2007a, 2007b). The 300 Area, in the southeastern corner of the reservation, was home to facilities for nuclear fuel rod fabrication. A map of the site is shown in Fig. 1. Between 1943 and 1975, basic sodium aluminate and acidic $\mathrm{Cu}$ - and $\mathrm{U}$-bearing wastes from these activities (e.g., dissolved fuel assemblies) were discharged to the North and South Process Ponds (Zachara et al., 2005 and references therein). The $\mathrm{pH}$ of the pond water varied between 1.8 and 11.4 over the lifetime of the ponds, and $\mathrm{NaOH}$ was frequently added to neutralize the wastewater and prevent acidic solutions from leaching down through the vadose zone to the groundwater. Nevertheless, chemical leaching from these ponds produced a plume of contaminated groundwater that has existed for over 30 years and continues to discharge $\mathrm{U}$ into the adjacent Columbia River to this day (Peterson et al., 2008).

It has been hypothesized that seasonal changes in the water table, driven by fluctuations in river stage, make the 300 Area vadose zone an ongoing source of uranium to both the groundwater and the river (Qafoku et al., 2005; Zachara et al., 2005; Peterson et al., 2008). The 300

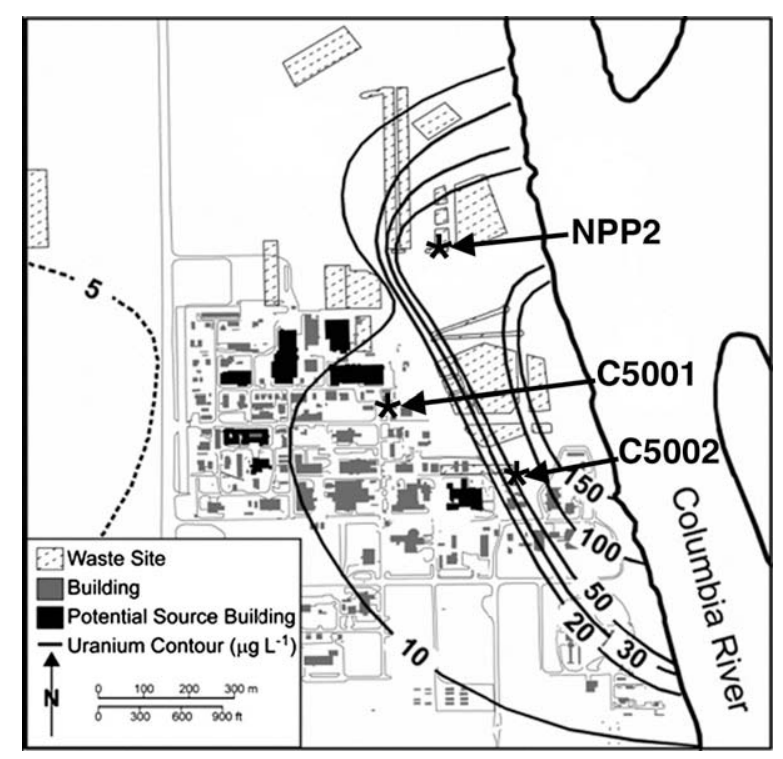

Fig. 1. Map of Hanford 300 Area. Contaminated samples are from the location marked NPP2. Uncontaminated samples are from boreholes C5001 and C5002, and were collected from a region of the vadose zone above the uranium plume. Uranium groundwater concentrations (uranium contours) were measured in December 2002.
Area vadose zone is comprised of Pleistocene-age, catastrophic flood deposits of the Hanford formation (Baker et al., 1991; DOE, 2002), which are composed of poorly sorted river cobble, gravel, sand, silt, and clay. Although sediments from the 300 Area have been studied extensively using a variety of spectroscopic and diffraction techniques (Wang et al., 2005; Catalano et al., 2006; Arai et al., 2007; McKinley et al., 2007b), much remains unknown about $\mathrm{U}$ speciation in them, largely due to limitations in the availability of high-resolution chemical, structural, and textural data to describe the materials that host U.

Electron microprobe analysis (EMPA) has long been used to acquire chemical analyses in textural context at the micron scale in a variety of materials. Likewise, transmission electron microscopy (TEM) is a well-established technique for obtaining images as well as chemical and diffraction data from materials at the nanometer-scale. Here we bridge the two methods, using a focused ion beam (FIB) to extract cross-sections of fine-grained U-bearing materials located with EMPA, so that they may be more fully investigated in the TEM. Our approach integrates microscopies and spectroscopies across many scales, and can be applied to the identification of fine-grained contaminant hosts in all contaminated solids. Significant new advances in understanding the complex solid-phase residence of $U$ in these sediments were achieved.

\section{MATERIALS AND METHODS}

\subsection{Contaminated sediments}

Contaminated sediments were collected from a region of the vadose zone directly beneath the former North Process Ponds (Fig. 1). Two remediation campaigns (in 1996 and 2003) removed several meters of highly contaminated materials prior to the collection of the samples under investigation. These samples, numbered NPP2-2 and NPP2-4 were collected in the spring of 2003 , from 0.6 and $1.2 \mathrm{~m}$ below the ground surface that existed following the remediation events. The samples contain 84.24 and $157.87 \mathrm{mg} / \mathrm{kg} \mathrm{U}$, respectively (this study). Previous studies indicate that $\mathrm{U}$ in these sediments occurs predominantly in the hexavalent oxidation state (Catalano et al., 2006; Arai et al., 2007). At the time of sample collection, the water table was $3.0 \mathrm{~m}$ below the excavated ground surface (Zachara et al., 2005; Catalano et al., 2006; Bond et al., 2008).

\subsection{Uncontaminated sediments}

We also investigated six uncontaminated sediment samples (three samples each from two boreholes) from the site. These were collected from the vadose zone above the uranium groundwater plume in the spring of 2006, from boreholes C5001 and C5002 that were located outside of the process pond footprints (Fig. 1). The C5001 sediments are from depths ranging from 7.5 to $12.6 \mathrm{~m}$ below ground surface (bgs), with the water table at $14.4 \mathrm{~m}$ bgs at the time of sampling. The C5002 sediments are from depths ranging from 7.5 to $12.0 \mathrm{~m}$ bgs, with the water table at $14.5 \mathrm{~m} \mathrm{bgs}$ (Williams et al., 2007). Although uranium concentrations 
in these samples $(1.3-1.7 \mathrm{mg} / \mathrm{kg})$ are at or near background levels (1.5-3 mg/kg) (Zachara et al., 2005; Williams et al., 2007), we cannot be certain that these sediments have never interacted with waste materials. Nevertheless, for simplicity, we will hereafter refer to these sediments as "uncontaminated." Like the contaminated sediments, the uncontaminated sediments are from the Hanford formation.

\subsection{Sample preparation and characterization}

All sediments were air-dried and sieved to $<2 \mathrm{~mm}$. They were embedded in epoxy and petrographic thin sections were prepared by Spectrum Petrographics, Vancouver, WA. These were polished without water in order to prevent dissolution or mobilization of sample constituents. Thin sections were examined in the petrographic microscope prior to study in the electron microprobe. Samples were carbon coated and electron microprobe analysis (EMPA) was carried out using a JEOL 8600 Superprobe operated at $15-25 \mathrm{kV}$ with a $20 \mathrm{nA}$ beam current. Backscattered electron imaging, which is sensitive to differences in mean atomic number, was used to locate areas of interest.

Initial chemical analyses were conducted using X-ray energy dispersive spectroscopy (EDS). The contaminated samples contain approximately 40 times more $\mathrm{Cu}$ than $\mathrm{U}$ (by weight), and Arai et al. (2007) noted a U-Cu correlation in NPP sediments. Thus, the presence of high concentrations of $\mathrm{Cu}$ (well in excess of background, which is $18.4 \mathrm{mg} / \mathrm{kg}$ ) provided a proxy for interaction of sediment constituents with the pond waste, and a useful guide in the search for $\mathrm{U}$, even where $\mathrm{U}$ was not initially detected. In materials of interest where $U$ concentration was too low to be detected by EDS, wavelength dispersive spectrometers (WDS) were scanned over uranium and other trace element peaks. WDS lines scans across regions of interest in the sample were used to explore the spatial distribution of uranium in sediment coatings.

Quantitative WDS chemical analysis was conducted for the Zr-rich material (described below) in order to measure $\mathrm{P}: \mathrm{Zr}$ and $\mathrm{U}: \mathrm{Zr}$ ratios. Fifteen elements $(\mathrm{Na}, \mathrm{Mg}, \mathrm{Al}, \mathrm{Si}$, $\mathrm{P}, \mathrm{K}, \mathrm{Ca}, \mathrm{Ti}, \mathrm{V}, \mathrm{Cr}, \mathrm{Mn}, \mathrm{Fe}, \mathrm{Cu}, \mathrm{Zr}$, and $\mathrm{U}$ ) were analyzed. Uranium hosts were extracted and thinned for transmission electron microscopy (TEM) with an FEI Nova 600 DualBeam focused ion beam (FIB) instrument using an in-situ lift-out technique similar to the ones described by Giannuzzi et al. (2005) and Kamino et al. (2005). A Philips CM300 FEG TEM, operated at $300 \mathrm{kV}$, was used for imaging and EDS chemical analysis at a higher spatial resolution than that achievable in the electron microprobe. Crystalline phases were identified using selected area electron diffraction (SAED) in the TEM.

The total concentrations of $\mathrm{Zr}$ and $\mathrm{U}$ in the $<2 \mathrm{~mm}$ sediment samples were determined by fusion and dissolution (Crock and Lichte, 1982), with subsequent ICP-MS analyses (Lichte et al., 1987). For this procedure, the samples were ground ( $2 \mathrm{~g})$, mixed with an equal mass of lithium tetraborate $\left(\mathrm{Li}_{2} \mathrm{~B}_{4} \mathrm{O}_{7}\right)$, and fused in a carbon crucible at $1000{ }^{\circ} \mathrm{C}$ for $30 \mathrm{~min}$. The fusion bead was ground; $250 \mathrm{mg}$ was dissolved in $6 \mathrm{~mL} \mathrm{HF}, 2 \mathrm{~mL} \mathrm{HNO}_{3}$, and $2 \mathrm{~mL}$ of
$\mathrm{HClO}_{4}$; and the acid mixture evaporated to dryness at $110^{\circ} \mathrm{C}$. The residue was subject to a second evaporation step with $2 \mathrm{~mL} \mathrm{HClO}_{4}$ at $165^{\circ} \mathrm{C}$, with subsequent addition of $3 \mathrm{~mL} \mathrm{HNO}_{3}, 8$ drops of $\mathrm{H}_{2} \mathrm{O}_{2}, 3$ drops of $\mathrm{HF}$, and an internal standard of In, Re, and Ru (Doherty, 1989) when cooled. The sample was then diluted to $60 \mathrm{~mL}$ final volume. The procedure completely dissolves refractory phases such as zircons, garnets, and U-containing Ti-oxides (an important detrital U-containing phase in Hanford sediment) (Zachara et al., 2007a). Final analysis was performed using a Hewlett Packard model 4500 ICP-MS with plasma power of $1300 \mathrm{~W}$. Analytical precision based on repeated analyses $(N=54)$ of an international standard and given as a coefficient of variation in \% (i.e., SD/mean $\times 100$ ) was 6.51 for $U$ and 1.57 for Zr. Additional details on methodology, precision, and accuracy are available (http://www.sees.wsu.edu/ Geolab/note.html).

\section{RESULTS}

\subsection{Sediment texture and composition}

Modal abundances of rock and mineral fragments as well as clast coatings and loose fines were determined by point-counting using a petrographic microscope, and are shown in Table 1. Between 1890 and 2113 points were counted per thin section, $28-38 \%$ of which were embedding epoxy. Epoxy points were subtracted from the total and the remaining points were renormalized to $100 \%$. The sediments in both the contaminated and uncontaminated samples are composed chiefly of basalt fragments. They also contain lesser amounts of granite, sandstone, and metamorphic lithic fragments, as well as monomineralic grains of quartz, feldspars, micas, and opaque minerals. Many of the opaques probably originated in the basalt. Materials that were too fine to be readily identified with optical petrography were divided into the categories "coatings" and "loose fines" based on their textural relationships to the larger sediment clasts, many of which are surrounded by fine-grained material, and on their apparent cohesiveness. In both categories, only fines that were parts of larger masses were counted. Nevertheless, both the coatings and the masses of loose fines are porous, and therefore the fines may, in general, be overrepresented in Table 1. When an isolated fine particle fell under the microscope's crosshairs it was counted as epoxy. It is worth noting that some of the materials counted as coatings may have adhered to the clasts during drying or sieving, and some of the loose fines, which are most abundant in the uncontaminated samples, may have originated in coatings and been abraded away in the sample collection and preparation process.

Despite similarities in the makeup of the central clasts, the coatings' textures and mineralogies differ substantially between contaminated and uncontaminated samples. In the contaminated samples, most coatings comprise materials that are too small to be identified using EMPA, although some contain larger mineral fragments. Many of the coatings in the contaminated samples are also distinctly layered. Clasts in the uncontaminated sediments are also surrounded by aggregated fines. These coatings, however, 
Table 1

Percent modal abundances of major clast types, coatings, and loose fines.

\begin{tabular}{|c|c|c|c|c|c|c|c|}
\hline Sample & Basalt $^{\mathrm{a}}$ & Granite Quartzite Sandstone & Quartz & Feldspar & Coating $^{\mathrm{b}}$ & Loose fines ${ }^{c}$ & Other $^{\mathrm{d}}$ \\
\hline \multicolumn{8}{|c|}{ Contaminated } \\
\hline NPP2-2 & $69(1)$ & $8.5(8)$ & $4.0(5)$ & $2.1(4)$ & $13(1)$ & $1.5(3)$ & $1.8(4)$ \\
\hline \multicolumn{8}{|c|}{ Uncontaminated } \\
\hline C5001-67B & $25(1)$ & $6.6(7)$ & $9.8(9)$ & $5.8(7)$ & $31(1)$ & $17(1)$ & $5.9(7)$ \\
\hline C5001-69C & $76(1)$ & $7.4(7)$ & $2.2(4)$ & $1.3(3)$ & $7.5(7)$ & $3.6(5)$ & $1.9(4)$ \\
\hline C5001-71E & $53(1)$ & $11(1)$ & $6.1(7)$ & $4.5(6)$ & $15(1)$ & $6.8(7)$ & $3.6(6)$ \\
\hline C5002-87D & $36(1)$ & $6.6(7)$ & $8.4(8)$ & $3.8(5)$ & $27(1)$ & $14(1)$ & $4.5(6)$ \\
\hline C5002-90C & $43(1)$ & $6.1(7)$ & $5.7(7)$ & $3.4(5)$ & $31(1)$ & $8.0(8)$ & $2.2(4)$ \\
\hline C5002-91D & $52(1)$ & $9.1(8)$ & $4.1(5)$ & $1.6(3)$ & $21(1)$ & $8.6(7)$ & $3.5(5)$ \\
\hline
\end{tabular}

Estimated standard deviation in final digit shown in parentheses.

a Includes discrete olivine $(<1 \%)$, pyroxene $(<2 \%)$, and glass fragments $(1.0-3.2 \%)$ presumably derived from basalt.

b Includes clots of clay and silt in addition to material adhered to clasts.

c May have originated in coatings.

${ }^{\mathrm{d}}$ Includes opaques $(0.7-3.6 \%)$, micas $(<1 \%)$, carbonates $(<1 \%)$, and other minor clast types.

generally contain much coarser material than that found in the coatings on the contaminated sediments, and the layering sometimes found in the contaminated coatings is not seen in the uncontaminated samples (Fig. 2).

The striking differences in texture between contaminated and uncontaminated coatings have likely arisen from waste-sediment reactions in the contaminated sediments, driven by the passage of large volumes of waste solutions of both acidic and basic $\mathrm{pH}$. However, the Hanford formation is spatially heterogeneous, the flood deposits are chaotic in nature, and the depths of the contaminated samples below the original (unexcavated) ground surface are not known with certainty (Zachara et al., 2005). Thus, we are unable to assess precise stratigraphic relationships between our contaminated and uncontaminated samples, and it is possible that the uncontaminated sediments we examined are not exactly representative of what the contaminated sediments were like prior to construction of the ponds.

In both the contaminated and uncontaminated samples, many of the basalt clasts have internal voids, which are filled or lined to various extents with fine-grained material as shown in Fig. 3. Most of these voids contain or once contained volcanic glass, which is abundant in all of the samples, both within the basalt clasts and as separate fragments. Much of the glass shows evidence of alteration as a result of reaction with aqueous fluids. The term palagonite is used to denote such altered glass, although its definition is somewhat imprecise. The term is used here in its most general and comprehensive sense to include both amorphous, gel-like material and the crystalline products that grow as it ages. Readers interested in a detailed discussion of the evolution of palagonite and its aging products are directed to Stroncik and Schmincke $(2001,2002)$. In plane-polarized light, the palagonite in the Hanford samples ranges in color from pale, straw yellow to orange, and most of it is concentrically banded. Palagonite appears in both the contaminated and uncontaminated sediments; therefore its formation must not have resulted solely from reaction with the waste. Much of the palagonite found
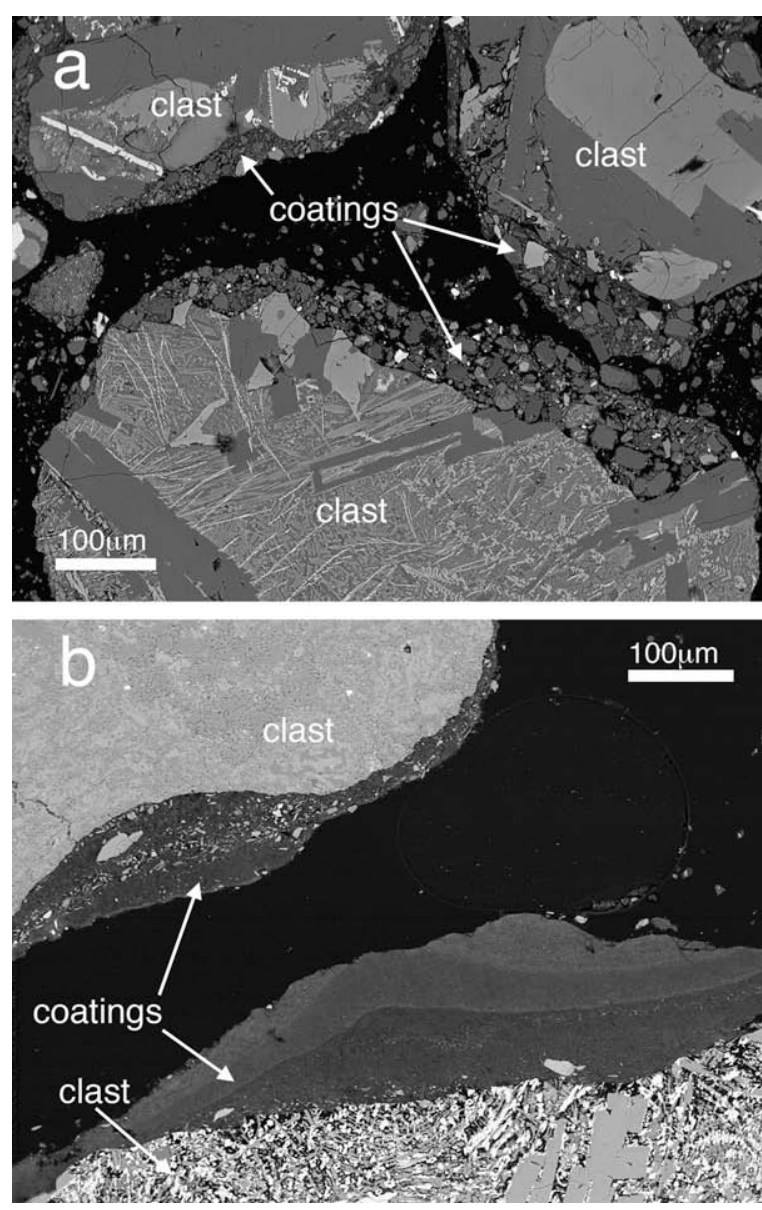

Fig. 2. BSE images of clast coatings from uncontaminated and contaminated sediments. Black regions are embedding epoxy. (a) Coatings in uncontaminated sediments are invariably coarse and contain fragments of rock-forming minerals in addition to material too fine to be identified using EMPA. (b) Most coatings in contaminated sediments are fine-grained, although some contain larger mineral fragments. Layering is common in the coatings of the contaminated sediments, and never seen in the uncontaminated sediments. 

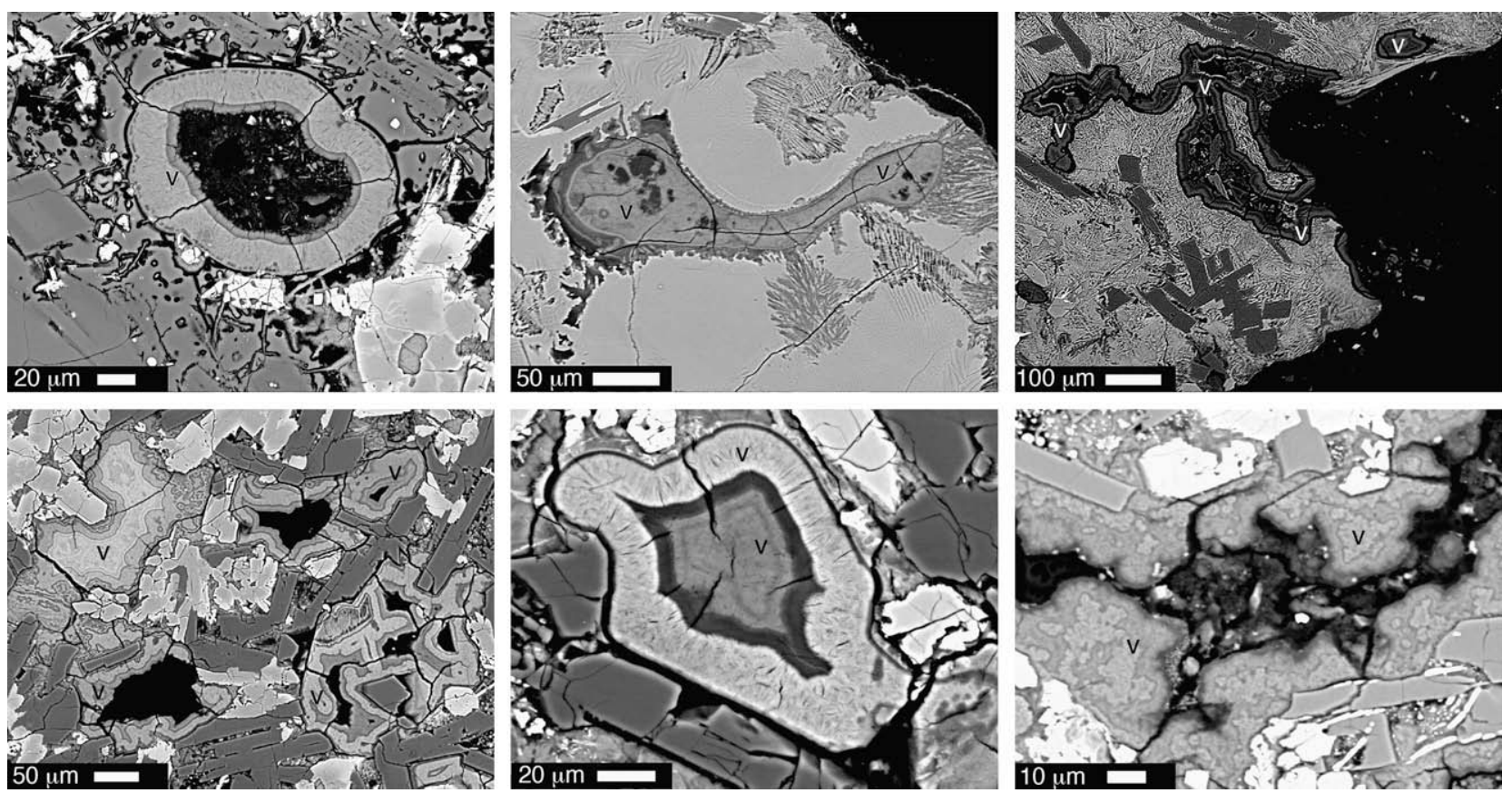

Fig. 3. BSE images of several voids in the contaminated samples. Voids are filled to various extents and the materials within them (v) are banded and display a variety of textures. Many of the cracks formed as a result of beam damage during imaging and analysis. Some voids, like the ones in Fig. 11, contain $\mathrm{U}$ in their linings, while in others $\mathrm{U}$ is not detected. High concentrations of $\mathrm{Cu}$ are found in all voids investigated in the contaminated samples, demonstrating that these internal portions in the lithic fragments were accessible to the contaminated fluids. Voids with similar textures are also found in the uncontaminated sediments.

within the basalt lithic fragments is optically anisotropic, indicating at least partial crystallinity. Textures observed in the microprobe are consistent with fine-grained, crystalline material (Fig. 3). Most of the palagonite surrounding the brown glass fragments is isotropic, indicating that it is amorphous. Laths of plagioclase feldspar extend from the brown, unreacted glass into the yellow, banded palagonite, indicating the banded material is not a coating deposited on the fragments after their formation, but rather is derived from the original glass. Many banded rims are surrounded by a nearly opaque (in plane-polarized light) lacey-textured material (Fig. 4).

\subsection{Uranium hosts}

We have identified six classes of uranium hosts in the contaminated sediments using EMPA. The two contaminated sediment samples are quite similar in terms of their textures, mineralogy, and the materials that host $\mathrm{U}$, and are treated together in the following text and figures, except where significant differences occur. Consistent with previous studies, we find $\mathrm{U}$ hosted by a $\mathrm{Cu}$-uranyl phosphate, presumed to be metatorbernite $\left[\mathrm{Cu}\left(\mathrm{UO}_{2}\right)_{2}\left(\mathrm{PO}_{4}\right)_{2} \cdot 8 \mathrm{H}_{2} \mathrm{O}\right]$, and by fine-grained coatings on sediment clasts (Catalano et al., 2006; Arai et al., 2007). We also find uranium in four newly recognized hosts in these vadose zone samples: (1) a Zr-rich amorphous material; (2) void linings in basalt clasts; (3) banded palagonite surrounding fragments of glass; and (4) Fe- and Mn-oxides. The coatings, void linings, banded palagonites, and $\mathrm{Fe}$ - and Mn-oxides do not contain suffi- cient $\mathrm{U}$ to be detected using EDS in the electron microprobe. However, WDS peak scans collected in some areas of each of these materials exhibit clear if small uranium peaks, as shown in Fig. 5. Rigorously quantitative EMPA, to determine $U$ concentrations in the hosts, is impossible because the $U$ hosts are fine-grained, intergrown with non-U-bearing materials, hydrous, and most were porous enough to allow infiltration of epoxy into pore spaces during the vacuum impregnation process. Samples of all six hosts have been prepared for TEM using a FIB instrument, and each host is described in more detail below.

\subsubsection{Metatorbernite}

The sediments from both NPP2-2 and NPP2-4 contain grains of a uranium phosphate mineral, which we have identified as metatorbernite, as described below. The grains are generally a few microns wide and up to a few tens of microns long. They occur mainly in or at the edges of clast coatings (Fig. 6). Because of their small size and relative scarcity, a modal abundance cannot be determined by EMPA (even if all of the $U$ in these samples was sequestered in metatorbernite, this mineral would make up less than $0.03 \%$ of the bulk sample by weight). Nevertheless, they are numerous enough to be located with relative ease with the electron microprobe in backscatter mode.

The Hanford uranium phosphate has a U:P atomic ratio of $1: 1$, as determined by standardless quantitative EDS in the electron microprobe. This is consistent with minerals of the meta-autunite group. These phosphates are also $\mathrm{Cu}$-bearing, and have been tentatively identified using 

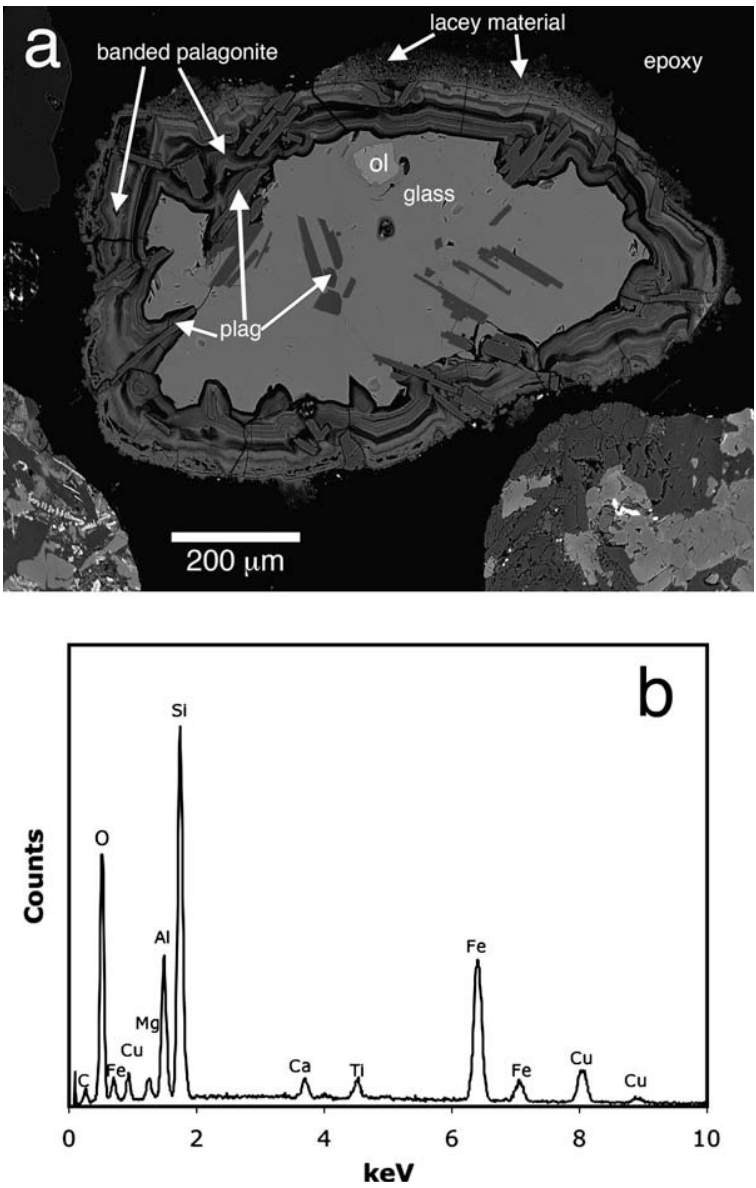

Fig. 4. (a) BSE image of banded palagonite and lacey material surrounding glass fragment. Palagonite formed during hydrous alteration of basaltic glass. Laths of plagioclase (plag) extend from glass fragment through palagonite, showing the banded material is not a coating that grew outward from the surface, but rather a reaction rim that has grown inward. Along with several plagioclase laths, an olivine crystal (ol), surrounded by smaller pyroxene crystals, is found within the central glass fragment. The palagonite contains U, as shown in Fig. 5. The lacey material also contains U. (b) Electron microprobe EDS from banded palagonite. The central glass fragment (EDS not shown) does not contain significant $\mathrm{Cu}$ (a proxy for interaction with waste) while the palagonite does. The palagonite and lacey material are chemically relatively similar.

extended X-ray absorption fine structure spectroscopy (EXAFS) and micro X-ray diffraction ( $\mu$-XRD) as metatorbernite (Catalano et al., 2006; Arai et al., 2007). Due to their fine scale and dispersed nature, positive identification of the phosphates requires the diffraction data and better constraints on chemistry afforded by the higher spatial resolution available in the TEM. Most phosphate grains in the samples are $<5 \mu \mathrm{m}$ wide and a few tens of microns long. These are, therefore, too small to prepare for TEM by conventional techniques, such as crushing or ion milling. The FIB allows for the selection and extraction of grains at the nanometer-scale, and so is ideally suited to the preparation of these samples. We have previously demonstrated that the FIB can be used to prepare high-quality TEM specimens of meta-autunite minerals (Elbert et al., 2007).

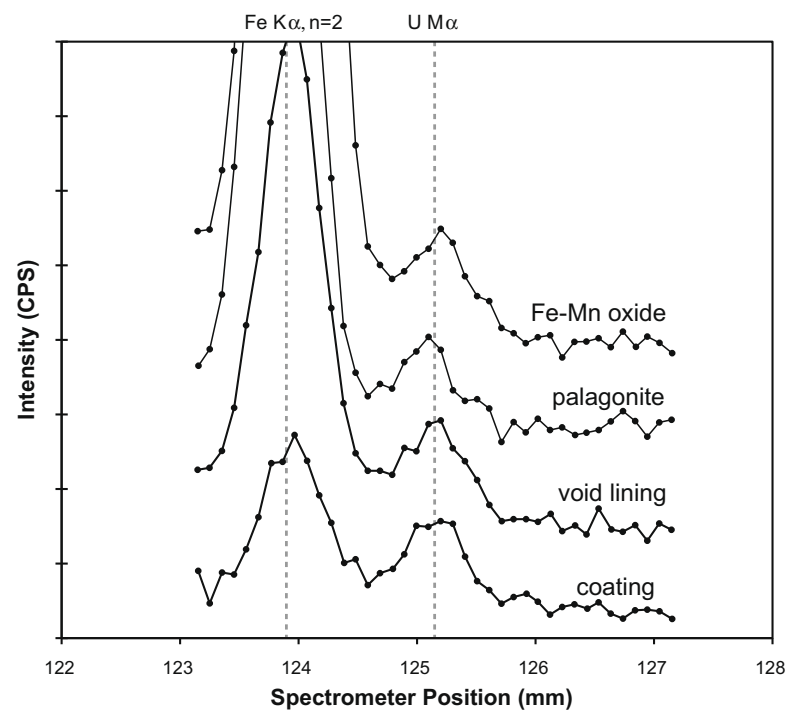

Fig. 5. Qualitative WDS peak scans from Fe-Mn oxide disks in weathered biotite (Fig. 12), banded palagonite (Fig. 4), a void lining (Fig. 11), and a fine-grained coating (Fig 6). Data points are averages of three analyses of $15 \mathrm{~s}$ each. The curves have been offset vertically for clarity, with tick marks on the vertical scale five counts-per-second (CPS) apart. The PET spectrometer was scanned over the second-order Fe $\mathrm{K} \alpha$ and first-order $\mathrm{UM} \alpha$ lines (vertical dashed lines). Each curve shows a small but clear UM $\alpha$ peak.

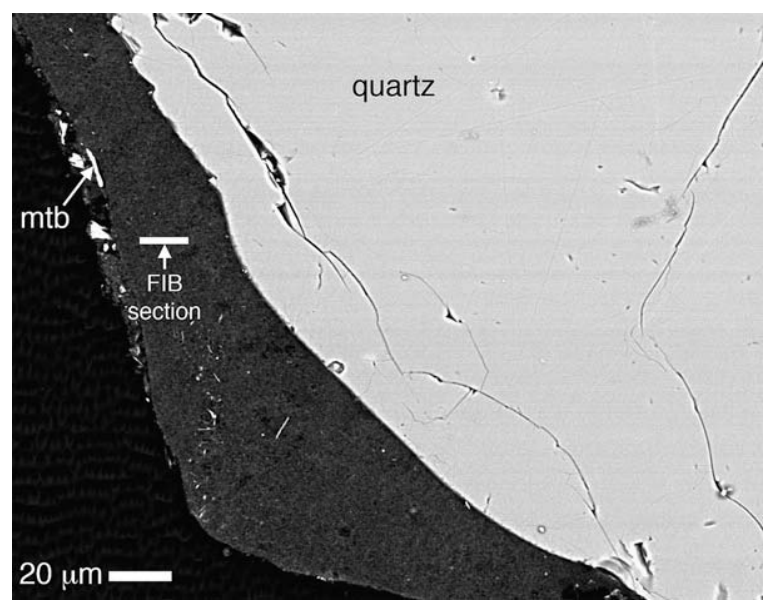

Fig. 6. BSE image of fine-grained coating on quartz clast. Metatorbernite $(\mathrm{mtb})$ is seen at the edge of the coating. Black material is epoxy. Location of a cross-section of the coating cut using the FIB for TEM analysis is shown.

FIB-prepared samples of the Hanford metatorbernite show little structural evidence of dehydration, even though Suzuki et al. (1998) observed a significant decrease in the basal spacing of metatorbernite in the TEM. SAED patterns collected in two orientations ( $\left[\begin{array}{lll}0 & 1 & 0\end{array}\right]$ and $\left[\begin{array}{lll}0 & 1 & \overline{1}\end{array}\right]$ zone axes) unequivocally identify the Hanford U-phosphate as metatorbernite, with crystallographic d-spacings that are consistent with the structural refinement published by Locock and Burns (2003). TEM EDS confirms that the 
phase is a $\mathrm{Cu}-\mathrm{U}$ phosphate (Fig. 7). Consistent with the SEM EDS results of Arai et al. (2007), the copper peak in our TEM EDS is smaller than expected for ideal metatorbernite. We have previously observed the rapid migration of $\mathrm{Cu}$ out of the analysis volume during electron microprobe analysis of metatorbernite, so this small peak is not surprising (Stubbs et al., 2007). There is no way to ascertain whether this phase originally grew as the fully hydrated torbernite (with 12 waters per formula unit) in a water-saturated environment. Even if this hydration state could be maintained in the high-vacuum environment of the TEM, the samples were air-dried prior to our receiving them, and at room temperature in air, metatorbernite is the stable phase. Furthermore, it is likely that the phosphate has converted back-and-forth between the fully and partially hydrated phases in the ground as water content in the sediments fluctuated.

\subsubsection{Clast coatings}

As described above, many of the rock and mineral fragments in the contaminated samples are coated with rinds of finer material. Some are made up of detrital mineral fragments including quartz, feldspars, pyroxenes, oxides, phyllosilicates, and other common rock-forming minerals, while most are composed mainly of fine-grained material whose components are too small to be identified using EMPA. WDS peak scans show that the fine coating in Fig. 6 contains $\mathrm{U}$ both near and tens of microns distant from the metatorbernite grain found at the edge. WDS peak scans also reveal $U$ in other (but not all) similarly textured coat- ings, even where metatorbernite is not found nearby. The FIB was used to prepare a TEM sample of the coating shown in Fig. 6. Because of its higher spatial resolution for both imaging and chemical analysis, the TEM allows us to show that while this coating is composed mainly of phyllosilicates, it also contains clay-sized grains of quartz, olivine, and Al-(oxyhydr)oxides (Fig. 8). SAED patterns were collected from several of the phyllosilicate grains shown in Fig. 8, and most indicate basal spacings $\sim 10 \AA$. One pattern indicated a basal spacing $\sim 14 \AA$. EDS reveals substantial variation in the $\mathrm{Si} A \mathrm{Al}$ ratios (from around 1-3) in these minerals. In general, they are iron-rich and alkali-poor. For reasons related to sample geometry, EDS spectra could not be collected from the same grains that were investigated using SAED. As determined by point-counting, coatings comprise $13 \%$ of sample NPP2-2 and 18\% of sample NPP2-4 (Table 1), and therefore represent a substantial potential reservoir for $\mathrm{U}$.

\subsubsection{Zr-rich material}

Many of the grain and clast coatings in NPP2-2 (but not in NPP2-4) have an outer rind of Zr-rich material that hosts minor amounts of uranium (Fig. 9). Cross-sections of several of these coatings were cut using the FIB. In the TEM, the Zr-rich material is amorphous. This suggests that it formed as an amorphous material, however, we cannot rule out the possibility that original crystallinity was damaged during either sample preparation (in the FIB) or analysis.
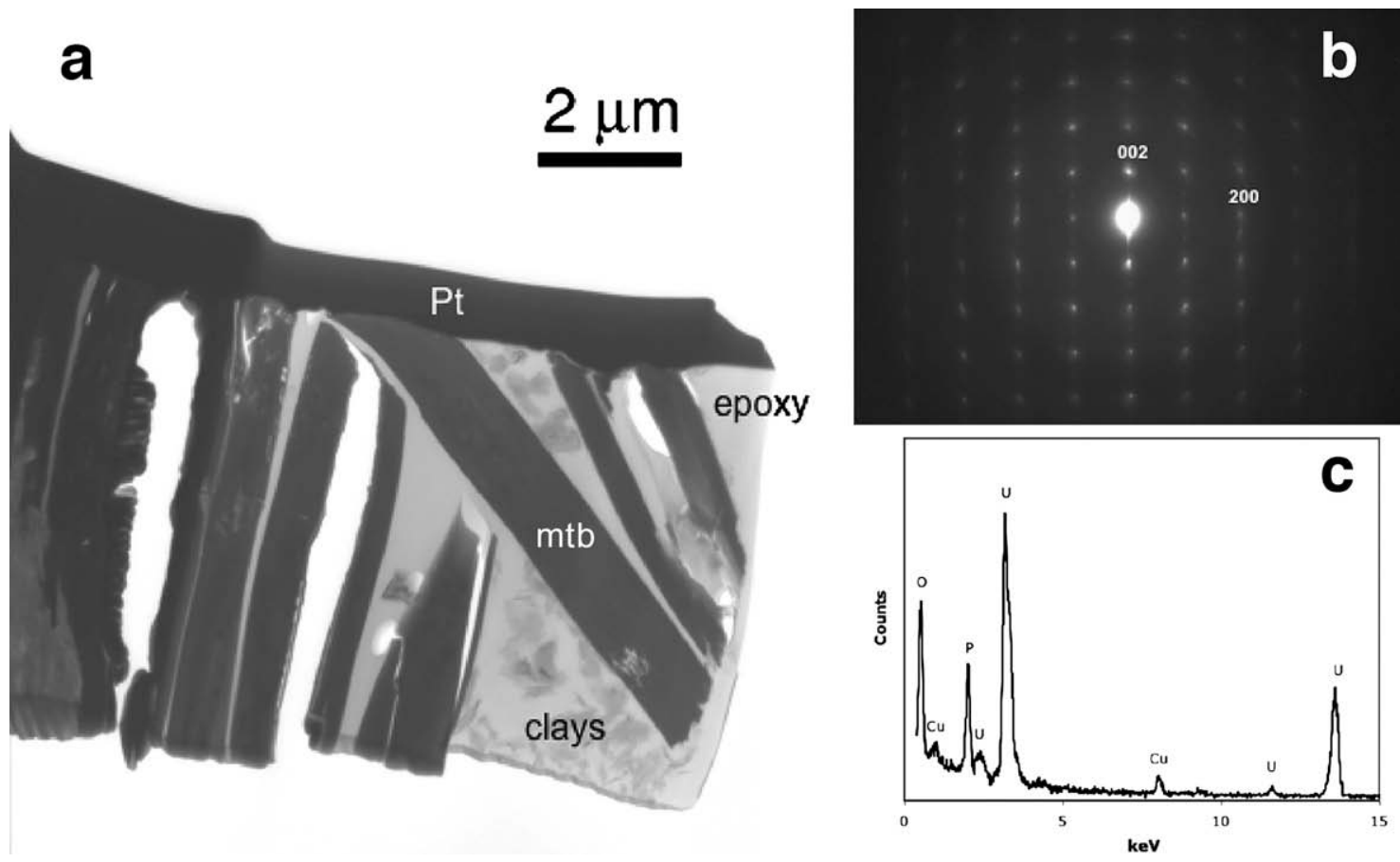

Fig. 7. (a) Bright-field TEM image of Hanford metatorbernite. The foil is mounted on a Mo grid. The dark gray bodies (mtb) are metatorbernite. The light gray material is embedding epoxy while most of the medium gray flakes are phyllosilicates (clays). Pt is a protective platinum strap deposited in the FIB prior to milling. (b) [010] SAED pattern. $d_{002}=8.61 \AA, d_{200}=3.48 \AA$, consistent with published structural refinements of metatorbernite. (c) TEM EDS of Hanford metatorbernite confirms that the phase is a $\mathrm{Cu}-\mathrm{U}$ phosphate. $\mathrm{Cu}$ peak is small because $\mathrm{Cu}$ is lost during analysis. 


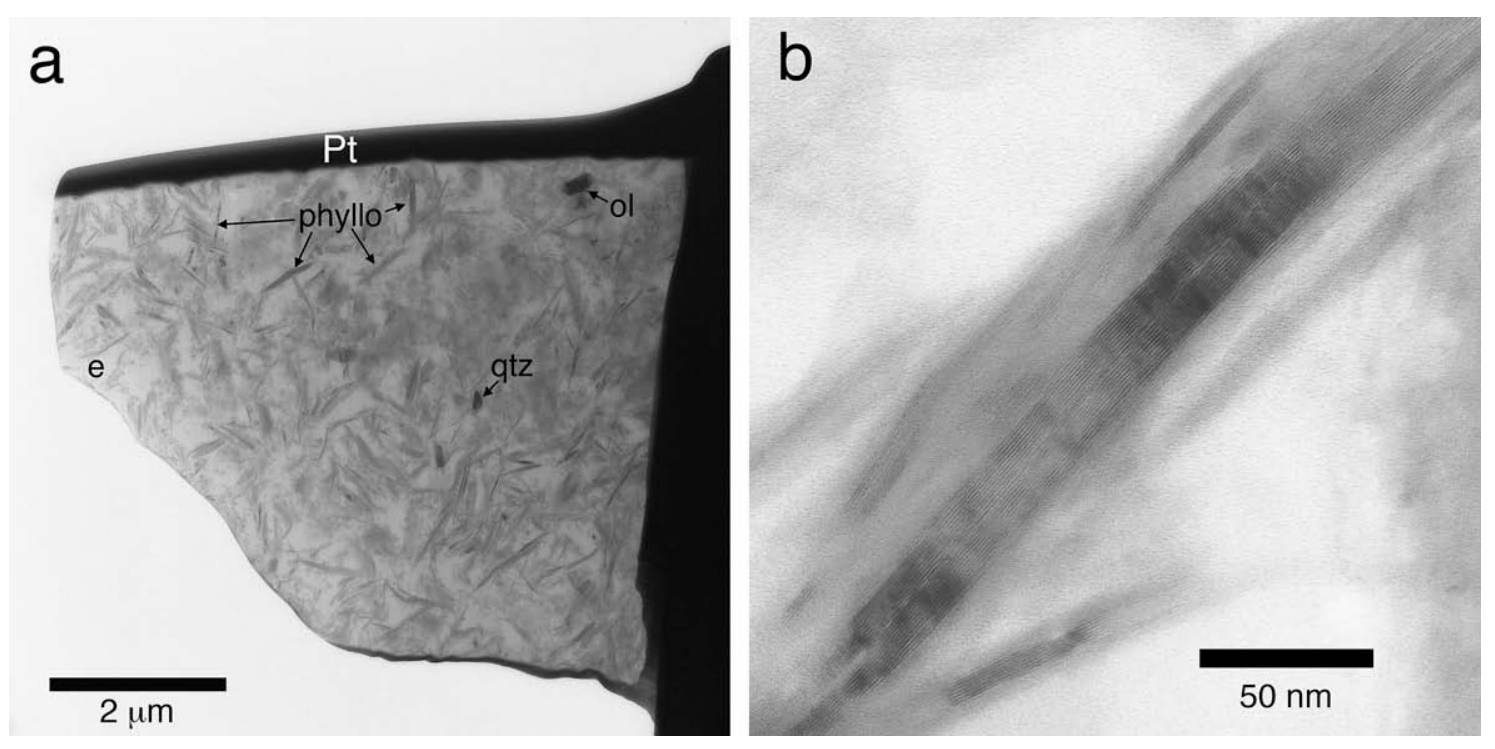

Fig. 8. (a) BFTEM image of FIB section cut from fine-grained coating in Fig. 6. Dark (strongly scattering), roughly equant particles are grains of rock-forming minerals, including olivine (ol) and quartz (qtz). Platy phyllosilicates (phyllo) are most distinct when oriented with their sheets parallel to the electron beam in a strongly diffracting condition. Tilting of the sample revealed that they also make up much of the medium gray, texturally indistinct material of the foil. Al-(oxyhydr)oxides are interspersed with the phyllosilicates. Featureless, pale gray material is embedding epoxy (e). (b) HRTEM image of a phyllosilicate grain showing $00 l$ lattice fringes. SAED shows this grain has a structure with a $00 l$ spacing of $\sim 10 \AA$.

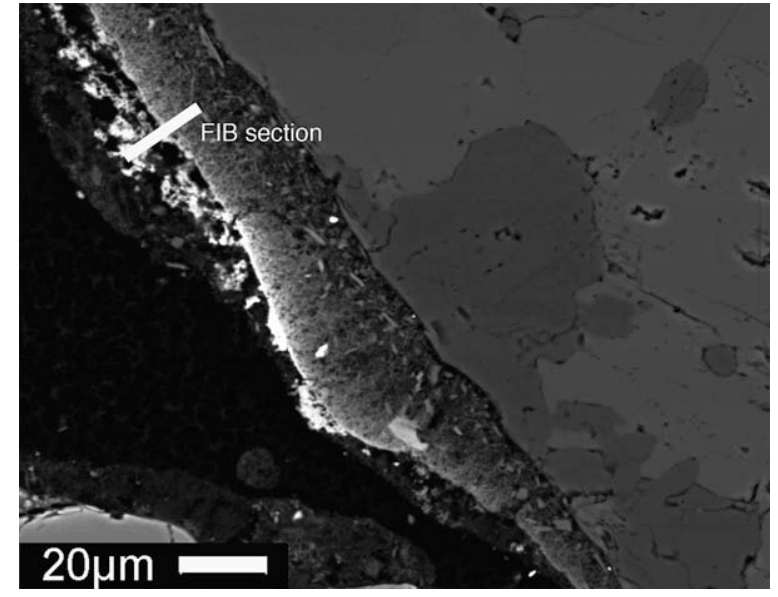

Fig. 9. BSE image of Zr-rich (bright) rim at the edge of a coating on a lithic fragment. Black material is epoxy. Location of a crosssection cut using the FIB for TEM analysis is shown.

The Zr-rich material appears in at least two distinct settings and textures, as exemplified in Fig. 10a. In the first, it appears as isolated aggregates, not intermixed with other soil minerals. This is usually found at the outer edge of the grain and clast coatings. In the second, it is intermixed with the fine mineral grains of the coatings. In Fig. 10b, it can be seen as a coating on the surfaces of individual mineral grains. Many of these particles have platy morphologies and basal spacings $\sim 10 \AA$, as measured by SAED, suggesting they are 2:1 sheet silicates. EDS shows that they are iron-rich and alkali-poor (Fig. 10d).

TEM EDS (Fig. 10c) suggests that the Zr-rich material is a zirconium oxide that contains lesser amounts of $\mathrm{Al}$,
$\mathrm{Ca}, \mathrm{Ti}, \mathrm{Cr}, \mathrm{Fe}, \mathrm{Cu}$, and $\mathrm{U}$. The $\mathrm{C}$ peak in Fig. 10c probably arises from the epoxy in which the sample was embedded prior to thin sectioning, however, the presence of natural carbonate cannot be ruled out. The Zr-rich materials shown in regions "I" and "II" of Fig. 10a are chemically indistinguishable with EDS. EDS collected from the Zr-rich material in other samples is similar, but can contain $\mathrm{V}$ and have some variability in the peak intensities of the minor and trace constituents. Importantly, the presence of $\mathrm{P}$ cannot be determined with EDS, since the $\mathrm{ZrL} \alpha$ peak $(2.04 \mathrm{keV})$ almost exactly coincides with the $\mathrm{PK} \alpha$ peak $(2.01 \mathrm{keV})$. Electron energy-loss spectroscopy (EELS), however, can resolve these peaks and shows that phosphorus is indeed present. The P:Zr atomic ratio (as measured using EELS) is 0.2. Although this material is too finely intergrown with the minerals of the coating to be isolated in the electron microprobe, quantitative WDS analyses were carried out to confirm the $\mathrm{P}: \mathrm{Zr}$ ratio (assuming all $\mathrm{Zr}$ and $\mathrm{P}$ in the analysis volume are in the $\mathrm{Zr}$-rich material). Fifty points were analyzed, whose mean $\mathrm{P}: \mathrm{Zr}$ atomic ratio is $0.24 \pm 0.05(95 \%$ confidence interval). Published $\mathrm{P}: \mathrm{Zr}$ atomic ratios from synthetic Zr-phosphates range from 0.69 to 2 (Amphlett, 1964), and most fall between 1 and 2 . We conclude, therefore, that the material is not a $\mathrm{Zr}$-phosphate, but is an oxide or (oxy)hydroxide either intergrown with particles of $\mathrm{Zr}$-phosphate or with adsorbed phosphate.

The only source we can identify for the $\mathrm{Zr}$ contamination in the 300 Area is dissolved fuel rod cladding alloy (e.g., zircaloy) (Serne et al., 2002), that may have been released during the latter periods of North Process Ponds' use. No specific records exist for $\mathrm{Zr}$ release to the North Process Ponds. Although $\mathrm{Zr}$ is not a contaminant of interest at Hanford because of low solubility at circumneutral 

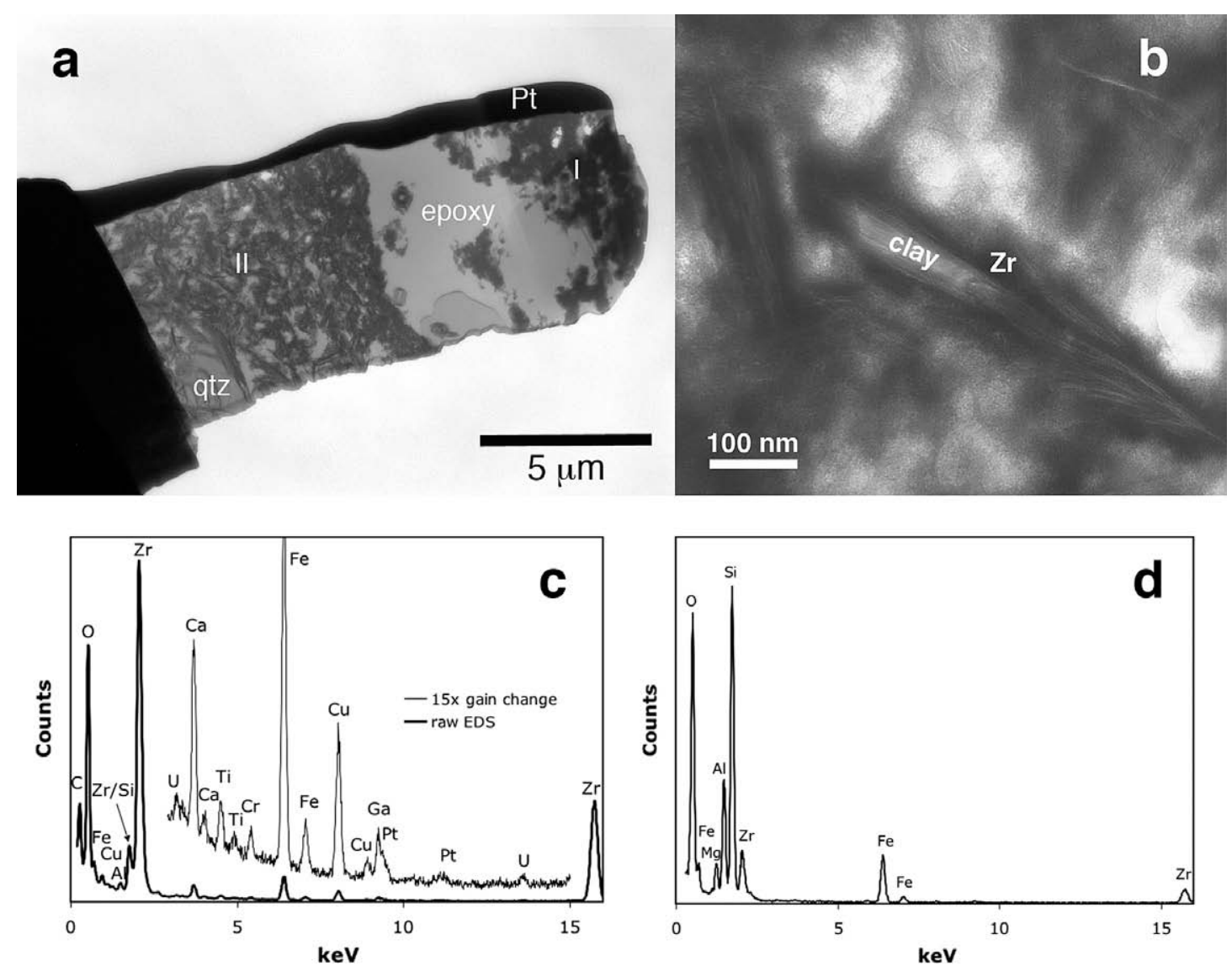

Fig. 10. (a) Bright-field TEM image of FIB-prepared specimen of Zr-rich coating in Fig. 9. The foil is mounted on a Mo grid. The region marked "I" contains only the Zr-rich coating. The region marked "II" contains mineral grains (mostly phyllosilicates) coated with the Zr-rich phase. Pt is a protective Pt strap deposited in the FIB, qtz is a quartz crystal. (b) Individual phyllosilicate mineral grain ("clay") coated with the Zr-rich phase. (c) TEM EDS from Zr-rich material. In addition to major $\mathrm{Zr}$ and O peaks, the spectrum shows minor amounts of $\mathrm{U}$, Al, $\mathrm{Ca}, \mathrm{Ti}, \mathrm{Cr}, \mathrm{Fe}$, and $\mathrm{Cu}$. Si may also be present. The presence of phosphorus cannot be ruled out with EDS since the $\mathrm{ZrL} \alpha$ peak overlaps the $\mathrm{PK} \alpha$ peak. The $\mathrm{C}$ peak probably arises from the epoxy in which the sample was embedded prior to thin sectioning, however, the presence of natural carbonate cannot be ruled out. Pt and Ga are sample preparation artifacts from the FIB. (d) EDS from central "clay" particle in (b). The $\mathrm{Zr}$ peaks may arise from the surrounding $\mathrm{Zr}$-rich phase, or $\mathrm{Zr}$ may be incorporated in the clay structure. Even when the vertical scale is adjusted no $\mathrm{U}$ peaks are visible.

$\mathrm{pH}$, the $\mathrm{Zr}$-rich material represents a reservoir for $\mathrm{U}$ that may directly or indirectly influence the thermodynamics and kinetics of $\mathrm{U}$ distribution between the sediment and water phase. Zirconium enrichment in the sediment phase from waste discharge was clearly evident: NPP2-2 contained $1065 \mathrm{mg} / \mathrm{kg} \mathrm{Zr}$, NPP2-4 contained $192 \mathrm{mg} / \mathrm{kg} \mathrm{Zr}$, and the uncontaminated sediments in Table 1 displayed an average background concentration of $171.6 \pm 9.7 \mathrm{mg} /$ $\mathrm{kg} \mathrm{Zr}$. We have not identified any other hosts for contaminant $\mathrm{Zr}$ in NPP2-2, and presume that all $\mathrm{Zr}$ in excess of background is in the $\mathrm{Zr}$-(oxyhydr)oxide.

$\mathrm{U}: \mathrm{Zr}$ ratios were also measured using WDS in the electron microprobe, again assuming the elements of interest occur only in the $\mathrm{Zr}$-oxide. The mean $\mathrm{U}: \mathrm{Zr}$ mass ratio is $0.015 \pm 0.003$. NPP2-2 contained $84.24 \mathrm{mg} / \mathrm{kg} \mathrm{U}$, and the average $\mathrm{U}$ concentration of the uncontaminated sediments was $1.54 \pm 0.17$. Thus, the $\mathrm{Zr}$-oxide accounts for $16 \pm 3 \%$ of the uranium budget in sample NPP2-2.

Extensive laboratory experiments have been conducted on the uptake of $U$ from aqueous solutions by crystalline and amorphous $\mathrm{Zr}$-(oxyhydr)oxides and Zr-phosphates (e.g., Amphlett, 1964; Gal and Ruvarac, 1964; Horwitz, 1966; Vesely et al., 1968; Ruvarac and Vesely, 1970; Marei et al., 1972; Aly et al., 1975; Pakholkov and Zelenin, 1988; Song et al., 1995; Plotnikov and Bannykh, 1997; Drot et al., 1999; Zhuravlev et al., 2002; Lomenech et al., 2003; Misaelides et al., 2006; Um et al., 2007; Finck et al., 2008). Early studies focused on the use of these materials as industrial ion exchangers, while more recent ones were designed to test their applicability to the remediation or prevention of $\mathrm{U}$ contamination in soils and natural waters. To our knowledge, however, ours is the first report of low-temperature uranium uptake from groundwater or pore water by one of these materials in the field.

\subsubsection{Void linings}

The basalt clast in Fig. 11 displays evidence of extensive alteration. Significant matrix material has been dissolved, leaving small openings that appear black in the BSE image. These form what appear to be interconnected paths 
through the clast, some of which join with large voids whose openings intersect the surface of the thin section. Some of these voids are subhedral, containing relict olivine and plagioclase, while the precursors of others, with rounded and irregular edges, are more difficult to determine. WDS peak scans of the materials lining both types of voids reveal that some of them contain U. A cross-section through the lining of one of the irregular voids was cut using the FIB and examined in more detail in the TEM (Fig. 11c). This void lining is divided into two distinct regions. The region closest to the center of the void contains material that appears crumpled or tangled in texture. This material resembles, in both chemistry and morphology, the fibrous precursors that are formed during the transition from volcanic glass to clay minerals like smectite (Buey et al., 2000 and references therein). The material is poorly crystalline and beam-sensitive, displaying few diffraction spots in SAED, which rapidly give way to amorphous rings. TEM EDS (Fig. 11d) shows this material contains signifi- cant amounts of $\mathrm{Si}$ and $\mathrm{Al}$ (with varying proportions of each in different locations), and lesser amounts of $\mathrm{Cu}, \mathrm{Fe}$, $\mathrm{Ca}$, and Ti. A small $\mathrm{U}$ peak is visible in the spectrum when a sufficiently long acquisition time (20-30 min) is used. The outer region is texturally featureless and contains only amorphous material, suggesting this void may have originally contained volcanic glass, although this amorphous material might also have been deposited upon reaction of the basalt with aqueous fluids. Uranium is not detected in the amorphous material adjacent to the minerals of the basalt.

The voids in the clast described above are not representative of all voids in the samples. Indeed, we have observed a great variety of void morphologies as well as void lining textures and extents to which the voids are filled (Fig. 3). Many of the voids contain palagonite, as described above. Most of the void linings we have investigated in the contaminated samples do not contain detectable $\mathrm{U}$, however all contain $\mathrm{Cu}$, and have therefore clearly interacted with
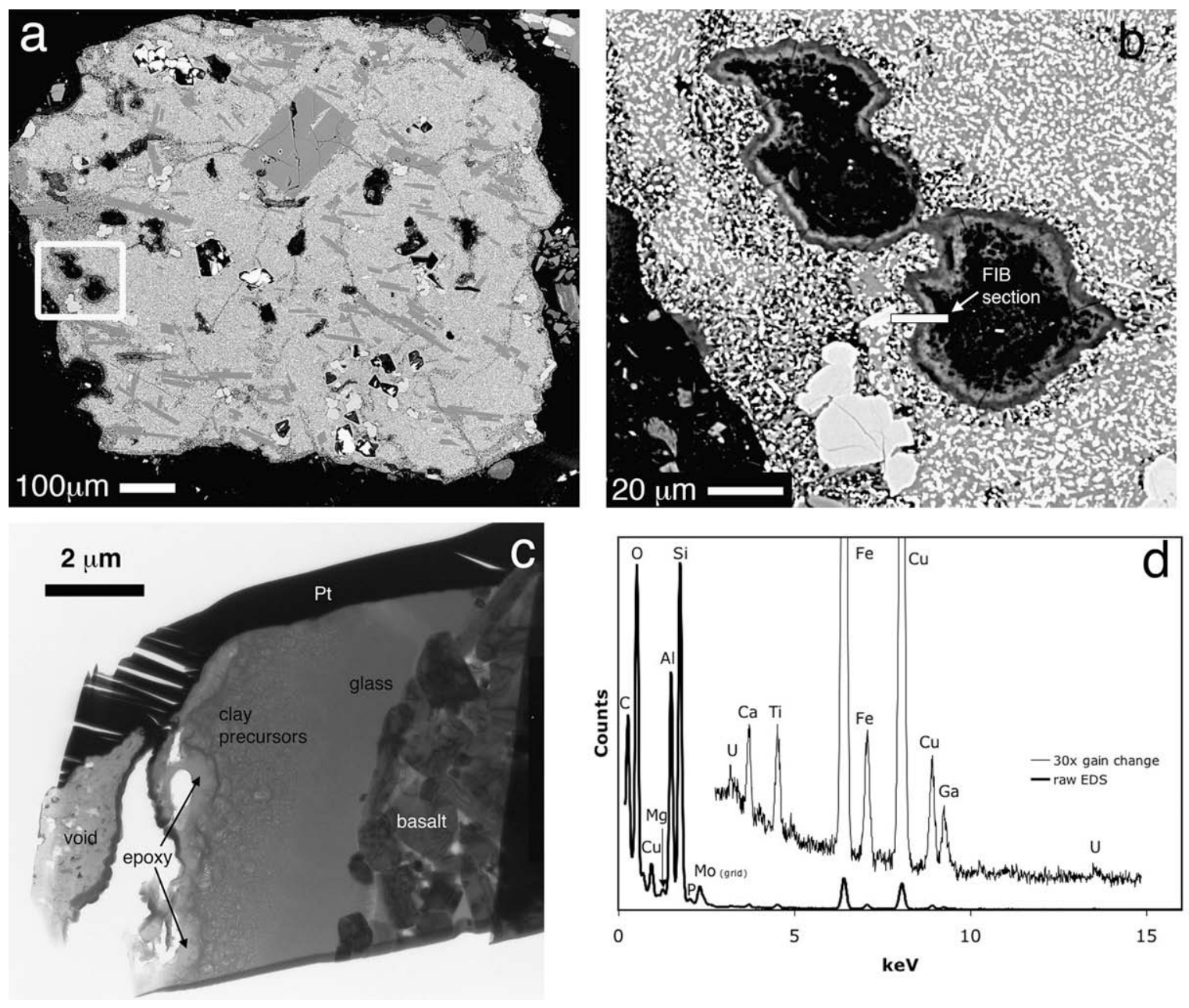

Fig. 11. (a) BSE image of weathered basalt clast with many voids; some are subhedral and contain remnants of olivine and plagioclase, others are irregularly shaped. (b) Rectangle in (a) at higher magnification showing position of FIB cross-section. Black areas within the clast are empty, and appear to have been dissolved away. (c) BFTEM image of FIB section. Pt is protective Pt strap deposited in FIB. Central void contains epoxy and crystals that are artifacts of sample preparation. Amorphous, featureless glass adjacent to the crystals of the basalt contains no detectable U. Textured clay precursors contain U, as shown with EDS (d). C peak likely arises from embedding epoxy and/or contamination due to long analysis time, Mo peak is from the TEM grid. 
the waste. McKinley et al. (2007a) found contaminant $\mathrm{Sr}$ associated with smectite in altered Hanford formation glasses (from the B Tank Farm) that are similar in appearance to some of the filled voids we observe in 300 Area vadose zone sediments.

\subsubsection{Banded palagonite on glass fragments}

Rims of banded palagonite surrounding glass fragments such as the one shown in Fig. 4 were analyzed using both EDS and WDS peak scans in the microprobe to identify regions that contained $\mathrm{U}$. The central glass fragment does not contain significant $\mathrm{Cu}$ (a proxy for interaction with waste), while the banded and lacey materials do contain $\mathrm{Cu}$. The banded palagonite and lacey material are chemically similar, although their Si:Al ratios differ. Most of the $\mathrm{Na}$ and $\mathrm{K}$ in the original glass have been lost during palagonitization, as has much of the Ca. WDS peak scans, such as the ones in Fig. 5, reveal that $\mathrm{U}$ is distributed heterogeneously throughout the thickness of the palagonite rims. The lacey material also contains $U$. $U$ is not found in the central glass. Three cross-sections of the yellow (in planepolarized light), banded material were prepared for TEM using the FIB. These U-bearing palagonite samples are all amorphous, consistent with previous descriptions of yellow, banded palagonite as a gel-like material (Stroncik and Schmincke, 2002). A sample of the lacey material was also prepared for TEM using the FIB. It contains crystalline minerals (phyllosilicates and Fe-oxides), in addition to poorly crystalline material resembling that shown in Fig. 11c.

\subsubsection{Fe- and Mn-oxides}

$\mathrm{Fe}-$ and Mn-oxides are found between the layers of several biotite grains (Fig. 12), as well as in some void linings, clast coatings, and loose fines. Some, but not all, of the oxides we have investigated contain sufficient $U$ to be detected with a WDS peak scan. A cross-section through one of the $\mathrm{Fe}-\mathrm{Mn}$ oxide disks shown in Fig. 12a was prepared in the FIB for TEM (Fig. 12b). This FIB-prepared sample contains (in addition to the original biotite) hematite, ferrihydrite, and mangansiderite, identified by SAED. $U$ is detected by TEM EDS only in regions containing ferrihydrite (Fig. 12e).

\section{DISCUSSION}

Catalano et al. (2006) examined sediments from the North Process Ponds including the NP sample series (collected before site excavation) and NPP2-0.5 and NPP2-4 (samples from the same excavation studied here) using bulk X-ray absorption spectroscopy (XAS), X-ray microprobe (XMP) analysis, and EMPA. They found uranium in discrete inclusions and clast coatings in vadose zone samples at shallow depth below the excavation interface (NPP20.5 and NPP2-4). Based on the results of linear-combination fitting of EXAFS reference spectra, they inferred that $43 \%$ of the U in sample NPP2-4 was sorbed to phyllosilicates and $55 \%$ was in metatorbernite, with the remaining $2 \%$ incorporated in calcite. In sample NPP2-0.5 (collected $0.15 \mathrm{~m} \mathrm{bgs}$ ), they inferred that $63 \%$ of $\mathrm{U}$ was sorbed to phyllosilicates, $22 \%$ was in metatorbernite, and $16 \%$ was incorporated in calcite. They did not look at sample NPP2-2.

Our observations also suggest that metatorbernite likely accounts for a significant portion of the uranium budget in this part of the vadose zone. The phyllosilicate-sorbed fraction of $U$ reported by Catalano et al. (2006) was determined using a silt/clay isolate from 300 Area aquifer sediments with adsorbed contaminant $U$ as a reference standard. This standard was polymineralic (containing smectite, chlorite, mica, and other phases), and likely contained adsorbed $\mathrm{U}$ on multiple phases. We have identified a wide variety of $\mathrm{U}$ hosts in these sediments, and it is likely that some portion of the phyllosilicate-associated uranium reported by Catalano et al. (2006) is associated with poorly crystalline and amorphous void linings and palagonites, the Fe-Mn oxides, and other aluminosilicate waste-sediment reaction products, in addition to the phyllosilicates that dominate the coatings. While we have identified the amorphous Zr-rich material as a U host, an EXAFS investigation would shed additional light on its nature. Such work could extend the linear-combination technique used by Catalano et al. (2006), and provide additional constraints on this material's significance in the uranium budget.

Based on combined micro X-ray fluorescence ( $\mu$-XRF) and $\mu$-XRD data with d-spacings between $\sim 2.8$ and $4 \AA$, Arai et al. (2007) reported the presence of metatorbernite and uranophane in sample NPP2-4. They also reported diffraction peaks consistent with calcite, K-feldspar, quartz, and muscovite collected from regions of this sample that contained intermediate to high concentrations of U. XAS measurements were consistent with the presence of autunite-group minerals and disordered U-carbonates at high $\mathrm{U}$ concentration spots in the sample. We did not find uranophane or carbonate-associated $U$ in samples NPP2-2 and NPP2-4, which is consistent with the results of Catalano et al. (2006) and McKinley et al. (2007b). McKinley et al. used bulk powder XRD of material scraped off of sediments to identify clinochlore and muscovite (with basal spacings of 14.24 and $10.01 \AA$ ) as major components of the clast coatings in the NPP samples. We found clasts of muscovite in both NPP2-2 and NPP2-4. However, although SAED shows that our U-bearing coatings contained phyllosilicates with basal spacings $\sim 10 \AA$, TEM EDS is not consistent with muscovite. Some of the intensity in the muscovite diffraction peaks presented in Arai et al. (2007) and McKinley et al. (2007b) could have arisen from the $10 \AA$ phyllosilicates described in this study. As argued above, the fine-grained coatings of the contaminated samples likely formed as a result of incongruent dissolution of the mineral fragments in coarse coatings like the ones in the uncontaminated samples. If this is the case, clay minerals and chlorite are more likely weathering products than muscovite.

\section{IMPLICATIONS}

The microscopic measurements performed herein provide important insights on physical and chemical factors controlling the solid-liquid distribution of contaminant $\mathrm{U}$ 

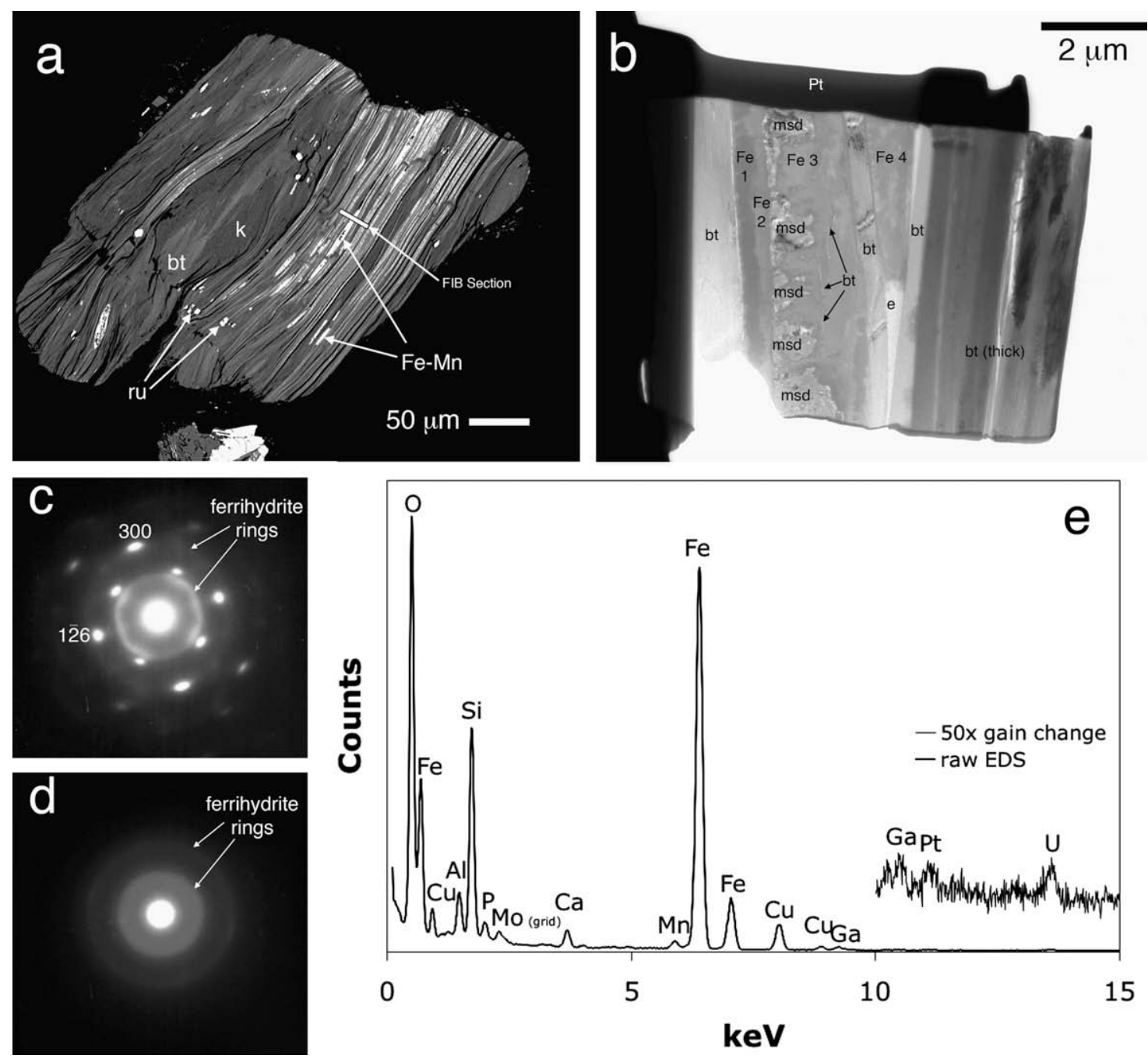

Fig. 12. Fe-Mn oxides in weathered biotite. (a) BSE image. Weathered biotite (bt) grain contains kaolinite (k), rutile (ru), and disks of Fe-Mn oxides. (b) BFTEM image of FIB section marked in (a). The right portion of the section has been left thick to enhance its structural stability. The section is mineralogically complex over short spatial scales, containing biotite (bt), Mn-bearing Fe-oxides (Fe1 - Fe4), and the Fe-Mn carbonate mangansiderite (msd). Small grains of relict biotite are found within Fe3 (faint, linear features). (c) SAED from Fe1 shows diffuse spots corresponding to the [031] zone axis of hematite, and weak rings contributed by 2-line ferrihydrite at 1.5 and $2.5 \AA$. SAED from Fe 2 and $\mathrm{Fe}_{3}$ (not shown) display weaker hematite diffraction spots (in the same orientation) and stronger ferrihydrite rings than Fe1. (d) SAED from $\mathrm{Fe} 4$ shows only rings from 2-line ferrihydrite. (e) TEM EDS from Fe2. U is detected only in Fe2-Fe4, which contain more Si than does Fe1. The amount of $\mathrm{Mn}$ found in $\mathrm{Fe} 1-\mathrm{Fe} 4$ is spatially variable within these areas. Pt and Ga are sample preparation artifacts from the FIB.

in these sediments. A common characteristic of the contaminated sediments from this site, regardless of collection depth, is that sorbed $\mathrm{U}$ is released slowly to contacting waters in batch and column laboratory experiments (Qafoku et al., 2005; Bond et al., 2008; Liu et al., 2008). This behavior is one of several factors that have contributed to the unexpected long-term persistence of the groundwater U-plume (Peterson et al., 2008). The cause for this slow kinetic behavior has been experimentally elusive, as sediments from the site are coarse-textured with minimal concentrations of fines that typically cause such effects. The new measurements described here reveal that reactive components of the waste solutions have migrated deeply within internal weathered domains of basalt lithic fragments. Additionally, there are coatings of fine-grained secondary phases result- ing from waste-sediment reaction on many of the lithic fragments, and basaltic glass has weathered to nano-porous palagonite on select surfaces and internal cavities. Collectively, these observations support a conceptual model where contaminant $U$ is distributed in complex fashion between three-dimensional physical domains with different reactive surfaces and mineral phases, and different microscopic transport properties including nano- to micro-porosity, tortuosity, and apparent diffusivity. Such distribution may slow or prevent the attainment of global chemical equilibrium between adsorbed and precipitated $U$ species, and yield a kinetically dominated system. The high pore water velocities that are characteristic of both the vadose and saturated zones at this particular field site may further exaggerate non-equilibrium conditions. Consequently, 
meaningful long-term predictions of $U$ concentrations in either pore or groundwater of the site as required for remediation must explicitly consider the effects of multi-scale mass-transfer and kinetic processes.

The 300 Area, where these samples were collected, contains Hanford's highest combined in-ground inventory of U (45,557 kg in sites 316-1 and 316-2) (Zachara et al., 2007a). The site is proximate to the Columbia River, and is of considerable regional concern as a contaminant source. The geochemical speciation and solid-phase residence of $\mathrm{U}$ in contaminated sediments from this site have been studied by multiple investigators using different techniques (Wang et al., 2005; Zachara et al., 2005; Catalano et al., 2006; Arai et al., 2007; McKinley et al., 2007b; Singer et al., in press), with each study providing separate, unique, and non-redundant insights. Collectively this body of research has shown that: (i) a multi-technique/multi-investigator approach is necessary to adequately characterize the complex chemical and physical attributes of the contaminated samples; (ii) the speciation of $U$ is heterogeneous and involves multiple adsorbed and precipitated phases that vary between samples according to waste flow paths, $U$ concentration, and depth; (iii) $U$ exhibits unresolved spatial and molecular associations with $\mathrm{Cu}$ and other co-contaminants, such as $\mathrm{Zr}$ as shown herein, that may strongly influence $\mathrm{U}$ geochemical behavior; and (iv) sorbed $U$ exists in complex physical domains on particle surfaces and grain interiors where micro-transport is necessary for fluid-solid exchange. The effective remediation of this site, and other large sites like it worldwide, requires comprehensive scientific information of the sort described herein for long-term prediction and knowledgeable selection of remedial options.

\section{ACKNOWLEDGMENTS}

Funding support was provided by USDOE BES Grant \# DEFG01-06ER06-01 and the U.S. Nuclear Regulatory Commission Contract \# JCN-N6375 and JCN-Y6462. EMPA, FIB work, and TEM were conducted at Johns Hopkins University. Chemical digestion and ICP-MS analysis for total $\mathrm{Zr}$ and $\mathrm{U}$ concentrations were conducted at the Washington State University GeoAnalytical Lab. We are grateful to our Associate Editor, Dr. Donald Sparks, and to Dr. Jeffrey Catalano and two anonymous reviewers, for their thoughtful comments and suggestions.

\section{REFERENCES}

Aly H. F., Abdelrassoul A. A. and Zakareia N. (1975) Use of zirconium-phosphate for stability constant determination of uranium and antimony chlorocomplexes. Z. Phys. Chem. 94, $11-18$.

Amphlett C. B. (1964) Inorganic Ion Exchangers. Elsevier, New York.

Arai Y., Marcus M. K., Tamura N., Davis J. A. and Zachara J. M. (2007) Spectroscopic evidence for uranium bearing precipitates in vadose zone sediments at the Hanford 300-area site. Environ. Sci. Technol. 41, 4633-4639.

Baker V. R., Bjornstad B. N., Busacca A. J., Fecht K. R., Kiver E. P., Moody U. L., Rigby J. G., Stradling D. F. and Tallman A. M. (1991) Quaternary geology of the Columbia Plateau. In Quaternary Nonglacial Geology; Coterminous US (ed. R. B.
Morrison). Geological Society of America, Boulder, CO, pp. 215-250.

Bond D. L., Davis J. A. and Zachara J. M. (2008) Uranium(VI) release from contaminated vadose zone sediments: estimation of potential contributions from dissolution and desorption. In Adsorption of Metals by Geomedia II (eds. M. O. Barnett and D. B. Kent). Elsevier, Oxford, UK, pp. 375-416.

Buey C. D., Barrios M. S., Romero E. G. and Montoya M. D. (2000) Mg-rich smectite "precursor" phase in the Tagus Basin, Spain. Clays Clay Miner. 48, 366-373.

Catalano J. G., McKinley J. P., Zachara J. M., Heald S. M., Smith S. C. and Brown G. E. (2006) Changes in uranium speciation through a depth sequence of contaminated Hanford sediments. Environ. Sci. Technol. 40, 2517-2524.

Crock J. G. and Lichte F. E. (1982) Determination of rare earth elements in geologic materials by inductively coupled argon plasma/ atomic emission spectrometry. Anal. Chem. 54, 1329-1332.

Crowley K. D. (2007) Science and Technology needs for DOE Site Cleanup: Workshop Summary. National Academy Press, Washington, DC.

Davis J. A. (2004) Assessing of conceptual models for subsurface reactive transport of inorganic contaminants. Eos Trans. AGU, 85. doi:10.1029/2004EO440002.

DOE (2002) Standardized Stratigraphic Nomenclature for the PostRingold-Formation Sediments within the Central Pasco Basin, DOE/RL-2002-39, Rev. 0, USDOE.

Doherty W. (1989) An internal standardization procedure for the determination of yttrium and the rare-earth elements in geological materials by inductively coupled plasma mass spectrometry. Spectrochim. Acta Part B-Atomic Spectrosc. 44, 263-280.

Drot R., Simoni E. and Denauwer C. (1999) Structural environment of uranium (VI) species sorbed onto ZrP2O7: X-ray absorption spectroscopy study. C.R. Acad. Sci., Ser. IIc: Chim. 2, 111-117.

Elbert, D. C., Stubbs, J. E., Veblen, L. A. and Veblen, D. R. (2007) Uranium in contaminated soils. Frontiers in Mineral Sciences. Cambridge, UK (abstr.).

Finck N., Drot R., Lagarde G., Mercier-Bion E., Catalettel H. and Simoni E. (2008) Temperature effects on the interaction mechanisms between $\mathrm{U}(\mathrm{VI})$ and $\mathrm{Eu}(\mathrm{III})$ and $\mathrm{ZrP} 2 \mathrm{O} 7$ : experiment and modelling. Radiochim. Acta 96, 11-21.

Gal I. and Ruvarac A. (1964) Separation of plutonium from uranium + fission products on zirconium phosphate columns. J. Chromatogr. 13, 549-555.

Giannuzzi L. A., Kempshall B. W., Schwartz S. M., Lomness J. K., Prenitzer B. I. and Stevie F. A. (2005) FIB lift-out specimen preparation techniques: ex-situ and in-situ methods. In Introduction to Focused Ion Beams: Instrumentation, Theory, Techniques and Practice (eds. L. A. (Giannuzzi and F. A. Stevie). Springer, New York, pp. 201-228.

Hartman M. J., Morasch L. F. and Webber W. D. (2007) Hanford Site Groundwater Monitoring for Fiscal Year 2006, PNNL16346, USDOE.

Horwitz E. P. (1966) Sorption of certain transplutonium ions on amorphous zirconium phosphate. J. Inorg. Nucl. Chem. 28, 1469-1478.

Kamino T., Yaguchi T., Hashimoto T., Ohnishi T. and Umemura K. (2005) A FIB micro-sampling technique and a site specific TEM specimen preparation method. In Introduction to Focused Ion Beams: Instrumentation, Theory, Techniques and Practice (eds. L. A. Giannuzzi and F. A. Stevie). Springer, New York, pp. 229-245.

Lichte F. E., Meier A. L. and Crock J. G. (1987) Determination of rare earth elements in geological materials by inductively coupled mass spectrometry. Anal. Chem. 59, 1150-1157. 
Liu C. X., Zachara J. M., Qafoku N. P. and Wang Z. M. (2008) Scale-dependent desorption of uranium from contaminated subsurface sediments. Water Resour. Res. 44, 13.

Locock A. J. and Burns P. C. (2003) Crystal structures and synthesis of the copper-dominant members of the autunite and meta-autunite groups: torbernite, zeunerite, metatorbernite and metazeunerite. Can. Mineral. 41, 489-502.

Lomenech C., Drot R. and Simoni E. (2003) Speciation of uranium(VI) at the solid/solution interface: sorption modeling on zirconium silicate and zirconium oxide. Radiochim. Acta 91 , 453-461.

Marei S. A., Aly H. F. and Zakareia N. (1972) Exchange behavior of tin, antimony and uranium in aqueous/nonaqueous media on cation-exchanger zirconium phosphate. Fresen. Z. Anal. Chem. 258, 282-283.

McKinley J. P., Zachara J. M., Smith S. C. and Liu C. (2007a) Cation exchange reactions controlling desorption of Sr-90(2+) from coarse-grained contaminated sediments at the Hanford site, Washington. Geochim. Cosmochim. Acta 71, 305-325.

McKinley J. P., Zachara J. M., Wan J., McCready D. E. and Heald S. M. (2007b) Geochemical controls on contaminant uranium in vadose Hanford formation sediments at the 200 area and 300 area, Hanford Site, Washington. Vadose Zone J. 6, 1004-1017.

Misaelides P., Gallios G., Sarri S., Zamboulis D., Pavlidou E., Kantiranis N., Anousis I., Zhuravlev I. and Strelko V. V. (2006) Separation of uranium from aqueous solutions using $\mathrm{Al}^{3+}$ - and $\mathrm{Fe}^{3+}$-modified titanium- and zirconium phosphates. Sep. Sci. Technol. 41, 97-110.

Pakholkov V. S. and Zelenin V. I. (1988) Interaction of uranium(VI) ions with cryogranulated titanium, zirconium, and niobium hydroxides under sorption. Sov. Radiochem. 30, 492497.

Peterson R. E., Rockhold M. L., Serne J., Thorne P. D. and Williams M. D. (2008) Uranium contamination in the subsurfaces beneath the 300 Area, Hanford Site, Washington, PNNL17034, USDOE.

Plotnikov V. I. and Bannykh V. I. (1997) Sorption of uranium(VI) by metal hydroxides. 1. Sorption of uranium(VI) by tetravalent metal hydroxides. Radiochemistry 39, 158-161.

Qafoku N. P., Zachara J. M., Liu C. X., Gassman P. L., Qafoku O. S. and Smith S. C. (2005) Kinetic desorption and sorption of U(VI) during reactive transport in a contaminated Hanford sediment. Environ. Sci. Technol. 39, 3157-3165.

Ruvarac A. and Vesely V. (1970) Thermodynamics of uranyl ion exchange on zirconium phosphates of various crystallinities. $J$. Inorg. Nucl. Chem. 32, 3939-3948.

Serne R. J., Brown C. F., Schaef H. T., Pierce E. M., Lindberg J., Wang Z., Gassman P. L. and Catalano J. G. (2002) 300 Area Uranium Leach and Adsorption Project, PNNL-14022, USDOE.

Singer D. M., Zachara J. M. and Brown G. E. (in press) Uranium speciation as a function of depth in contaminated Hanford Sediments: a micro-XRF, micro-XRD, and bulk- and microXAFS study. Environ. Sci. Technol.
Song Y. J., Hui Z., Yang Q. L. and Zhao A. M. (1995) Preparation, characterization of crystalline zirconium phosphates and study on their acid stability and ion exchange behavior with uranyl ions. J. Radioanal. Nucl. Chem. Art. 198, 375-384.

Stroncik N. A. and Schmincke H. U. (2001) Evolution of palagonite: crystallization, chemical changes, and element budget. Geochem. Geophys. Geosyst. 2. Paper number 2000GC000102.

Stroncik N. A. and Schmincke H. U. (2002) Palagonite-a review. Int. J. Earth Sci. 91, 680-697.

Stubbs J. E., Elbert D. C., Veblen L. A. and Veblen D. R. (2007) Rapid Cation Depletion During Electron Microprobe Analysis of Uranium Phosphates. Eos Transactions $A G U$ 88, Fall Meet. Suppl., V51A-0324 (abstr.).

Suzuki Y., Murakami T., Kogure T., Isobe H. and Sato T. (1998) Crystal chemistry and microstructures of uranyl phosphates. Mat. Res. Soc. Symp. Proc. 506, 839-846.

Um W., Mattigod S., Serne R. J., Fryxell G. E., Kim D. H. and Troyer L. D. (2007) Synthesis of nanoporous zirconium oxophosphate and application for removal of U(VI). Water Res. 41, 3217-3226.

Vesely V., Ruvarac A. and Sedlakov L. (1968) Sorption of uranyl ions on zirconium phosphates at elevated temperatures. $J$. Inorg. Nucl. Chem. 30, 1101-1106.

Wang Z. M., Zachara J. M., McKinley J. P. and Smith S. C. (2005) Cryogenic laser induced U(VI) fluorescence studies of a U(VI) substituted natural calcite: implications to $\mathrm{U}(\mathrm{VI})$ speciation in contaminated Hanford sediments. Environ. Sci. Technol. 39, 2651-2659.

Williams B. A., Brown C. F., Um W., Nimmons M. J., Peterson R. E., Bjornstad B. N., Lanigan D. C., Serne R. J., Spane F. A. and Rockhold M. L. (2007) Limited Field Investigation Report for Uranium Contamination in the 300-FF-5 Operable Unit at the 300 Area, Hanford Site, Washington, PNNL-16435, USDOE.

Zachara J. M., Davis J. A., Liu C., McKinley J. P., Qafoku N. P., Wellman D. M. and Yabusaki S. B. (2005) Uranium geochemistry in vadose zone and aquifer sediments from the 300 Area uranium plume, PNNL-15121, USDOE.

Zachara J. M., Brown C., Christensen J., Davis J. A., Dresel E., Liu C., Kelly S., McKinley J., Serne J. and Um W. (2007a) $A$ Site-Wide Perspective on Uranium Geochemistry at the Hanford Site, PNNL-17031, USDOE.

Zachara J. M., Serne J., Freshley M., Mann F., Anderson F., Wood M., Jones T. and Myers D. (2007b) Geochemical processes controlling migration of tank wastes in Hanford's vadose zone. Vadose Zone J. 6, 985-1003.

Zhuravlev I., Zakutevsky O., Psareva T., Kanibolotsky V., Strelko V., Taffet M. and Gallios G. (2002) Uranium sorption on amorphous titanium and zirconium phosphates modified by $\mathrm{Al}^{3+}$ or $\mathrm{Fe}^{3+}$ ions. J. Radioanal. Nucl. Chem. 254, 85-89.

Associate editor: Donald L. Sparks 